\title{
Evaluation of cardiovascular disease program in Sleman District, Indonesia
}

\author{
Liena Sofiana, Rokhmayanti Rokhmayanti, Sulistyawati, Desi Nurfita, Fardhiasih Dwi Astuti, Putri \\ Arum Sholekhati \\ Faculty of Public Health, Universitas Ahmad Dahlan, Yogyakarta, Indonesia
}

\begin{tabular}{l} 
Article Info \\
\hline Article history: \\
Received May 28, 2020 \\
Revised Jan 19, 2021 \\
Accepted March 4, 2021 \\
\hline
\end{tabular}

\section{Keywords:}

Cardiovascular disease

Evaluation

Hypertension

\begin{abstract}
Cardiovascular disease remains the biggest cause of death, while hypertension is the biggest risk factor for heart disease for 12 years from 2000 to 2012. Various programs to prevent and control hypertension have been carried out throughout the Sleman District Health Center, but the achievement of minimum service standards (SPM) hypertension has not met the target. The purpose of this study was to evaluate the cardiovasculer program in Sleman Regency, Indonesia. This research was mixed method design, with the sample consisted of 25 staff holding cardiovasculer program programs in health centers in Sleman Regency. The instruments used in this study were interview guides and check lists. Quantitative data analysis was conducted by entering data in spreadsheets and then categorizing, while qualitative analysis was conducted by using content analysis based on findings obtained from quantitative data. The results showed problems in the input aspect, namely the availability of human resources and facilities were still considered to be lacking, dual positions disturbed work effectiveness. In the aspect of the process it's good but there are still obstacles that are felt by the program holders. In the output aspect, Sleman Regency has not yet reached the SPM target for hypertension services.
\end{abstract}

This is an open access article under the CC BY-SA license.

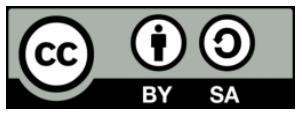

\section{Corresponding Author:}

Liena Sofiana

Faculty of Public Health

Universitas Ahmad Dahlan

Jalan Prof. Dr. Soepomo Janturan, Warungboto, Yogyakarta, Indonesia

Email: liena.sofiana@ikm.uad.ac.id

\section{INTRODUCTION}

Cardiovascular disease is one of the non-communicable diseases which are the main cause of death and physical disability suffered by the people of Indonesia and the world today. Based on NHANES data the prevalence of cardiovascular disease in adults from 2013 to 2016 was $48 \%$ and the total number of cases in 2016 was 121.5 million. Studies conducted among United States that most cardiovascular sufferers are related to unhealthy lifestyles such as a risky diet, high systolic blood pressure, high body mass index, high cholesterol levels, smoking habits and low physical activity [1]. Cardiovascular disease remains the biggest cause of death, while hypertension is the biggest risk factor for heart disease for 12 years from 2000 to 2012 [2].

The results of Riskesdas in 2018 showed that the prevalence of several cardiovasculer program diseases in Indonesia was still relatively high, namely hypertension of $8.4 \%$, heart disease $1.5 \%$, and stroke $10.9 \%$ [3], while the results of Riskesdas in 2013 showed that the prevalence of hypertension was $9.4 \%$, heart disease $1.5 \%$, and stroke by $7.0 \%$. Riskesdas data in 2013 also showed that the prevalence of hypertension sufferers in DIY was still relatively high at $12.8 \%$, heart disease by $1.3 \%$ and stroke by $10.9 \%$ [4]. DIY 
health profile data for 2017 shows that hypertension sufferers in DIY based on 2018 integrated health center surveillance hospital data in 398 cases [5].

The heart and blood vessel program carried out in Sleman Regency aims to prevent and overcome risk factors for heart disease and blood vessels. The cardiovascular disease program especially in hypertension that has been carried out in Sleman Regency is the chronic disease management program (Prolanis), integrated development post (Posbindu), and Elderly Posyandu. Data obtained from Riskesdas 2013 showed that the prevalence of hypertension in Sleman was $9.9 \%$, heart disease by $1.0 \%$, and stroke by $8.5 \%$ (4), while according to data from the health profile of Sleman in 2018 also showed that hypertension entered into the top ten diseases in Sleman Regency in second place with 66,618 cases. Various prevention and control programs for heart and blood vessel diseases, especially hypertension have been carried out in all Sleman District Health Centers, but the achievement of the coverage of the minimum service standards (SPM) of hypertension still has not met the target. Based on this, the researchers are interested in researching the evaluation of the heart disease and blood vessel (PJPD) program in Sleman Regency. Based on this, the researchers are interested in researching the evaluation of the heart disease and blood vessel program in Sleman Regency.

\section{RESEARCH METHOD}

This research was a in-front of mixed-method design. The study was a combination of quantitative and qualitative methods. Quantitative data includes input, process and output data from the implementation of the PJPD program, then qualitative data is obtained based on quantitative data with in-depth analysis. The sample consisted of 25 cardiac and vascular disease program staff staffing; the sampling technique was a total sample with a total 25 staff, at 25 primary health care in Sleman Regency, Indonesia on the grounds that 25 staff knows the data and implementation of the program. While those who were informants in qualitative research were those with the highest and lowest achievements including Non-communicable Disease Program Holders at the primary health care Depok 1, Turi Health Center, Moyudan Health Center, Elderly Posyandu Cadre, Posbindu Cadre. The instrument used in quantitative data is in the form of a checklist, while in qualitative data in the form of interview guides. Quantitative data analysis is done by entering data in a spreadsheet and then categorizing, while qualitative analysis is carried out using content analysis based on findings obtained from quantitative data. The validity of the data in this study uses source triangulation to see the validity of the information obtained by collecting data from various sources using the same method.

\section{RESULTS AND DISCUSSION}

\subsection{Input aspect}

An overview of the aspects of the input of hypertension prevention and control programs in the Sleman Regency of Yogyakarta Special Region can be described in Table 1.

Table 1. Input aspects of the cardiovasculer program

\begin{tabular}{|c|c|c|}
\hline Variable & Frequency (health center) & Percentage (\%) \\
\hline \multicolumn{3}{|c|}{ Availability of human resources } \\
\hline Available & 25 & 100 \\
\hline Unavailable & 0 & 0 \\
\hline \multicolumn{3}{|c|}{ Double position } \\
\hline Yes & 25 & 100 \\
\hline No & 0 & 0 \\
\hline \multicolumn{3}{|c|}{ Training for cadres } \\
\hline Yes & 23 & 92 \\
\hline No & 2 & 8 \\
\hline \multicolumn{3}{|l|}{ Funding } \\
\hline Adequate & 23 & 92 \\
\hline Inadequate & 2 & 8 \\
\hline \multicolumn{3}{|c|}{ Timeliness of funding } \\
\hline Yes & 24 & 96 \\
\hline No & 1 & 4 \\
\hline \multicolumn{3}{|c|}{ Hypertension program guidebook } \\
\hline Yes & 23 & 92 \\
\hline No & 2 & 8 \\
\hline \multicolumn{3}{|c|}{ Hypertension counseling media } \\
\hline Yes & 25 & 100 \\
\hline No & 0 & 0 \\
\hline \multicolumn{3}{|c|}{ Hypertension Checking Equipment } \\
\hline Yes & 25 & 100 \\
\hline No & 0 & 0 \\
\hline
\end{tabular}

Int. J. Public Health Sci., Vol. 10, No. 2, June 2021: 221 - 230 


\subsubsection{Human resources}

Based on Table 1, it can be seen that all primary health care in Sleman Regency have been responsible for the hypertension or non-communicable diseases program. Nevertheless, based on qualitative research conducted, all informants stated that the available human resources were considered insufficient in the implementation of prevention and control of hypertension programs. This is consistent with the following interview excerpt:

"The availability of human resources on average is lacking because the primary health care itself and the health department have limited human resources due to the moratorium. So, for approximately 8 years there has been no recruitment of Civil Servants. So, now there is a lack of human resources because many retire, some move, some die and there is no substitute." (Informant A)

"The organizer of this Non-Communicable Disease clearly has no special staff, so I am only a parttime officer and carrying out additional tasks. So, this is not my main task. Ideally, there are officers who specialize in non-communicable diseases." (Informant B)

"Still less, just two staff might still be lacking." (Informant C)

Based on quantitative and qualitative results, it can be seen that all primary health care in Sleman Regency already have a person in charge of the non-communicable disease (hypertension) program, but the number of implementers is still considered insufficient. Based on Table 1, it can be seen that all hypertension program managers have dual positions such as nurses, doctors, those in charge of other programs, and so on. This is also supported by the results of qualitative research. The following is an excerpt from the interview:

"The reason people hold concurrent positions at the primary health care is probably because of limited human resources and their optimality is disturbed because sometimes they have to report. The non-communicable disease programmer reported to us because he was busy with other programs. Busy in the School Health Unit, he is busy taking part in screening and then he has the position of treasurer to send the report, sometimes it takes quite a long time like that, because he has multiple positions like that." (Informant A)

"But the negative impact (dual position) is to become unfocused. That is because it is not the main duty and function, only while the output cannot also be full, we only leave the remaining main tasks. First basic tasks and only part time." (Informant B)

"Well, I must be tired because I also have work here and most of the Posbindu are outside when I work here." (Informant C)

"That is clearly quite tiring, confusing." (Informant D)

Based on the results of the quantitative and qualitative research, it can be seen that the concurrent positions of all holders of non-communicable disease programs (hypertension) in the Sleman District Health Center are considered tiring and reduce the effectiveness of work as the person in charge of noncommunicable diseases programs especially hypertension. Based on Table 1, it can be seen that the majority (92\%) of primary health care in Sleman District have conducted training for health cadres. This is also supported by the results of qualitative research. The following is an excerpt from the interview:

"Training, we always update knowledge. We are updating the knowledge for hypertension as well as we have Posbindu technical guidance for non-communicable diseases, Posbindu workshop, where later the biggest non comunicable disease from internal medicine doctors will convey to their health workers and to cadres, Posbindu non comunicable disease cadres. We train like that." (Informant A)

"The new cadre (who took part in the training) if not one, two." (Informant C)

"For us, it is more not just training for screening, miss, but training for officers is more towards the Posbindu." (Informant D)

"Yes (there is training), later before we carry out the task we will be trained first at the primary health care." (Informant E)

Health human resources are vital assets in an organization and cannot be replaced by other resources [6]. All primary health care in Sleman Regency currently have program managers in their efforts to prevent and control hypertension, but in the implementation of the availability of resources humans in the field are still considered inadequate. Sufficient quantity of human resources is needed to maximize existing health services, in addition, the large number of population now also demands an increase in the quantity of human 
resources [7]. All holders of hypertension prevention and control programs in Sleman Regency state that they assume double positions both as nurses, doctors, and other program holders. Multiple positions are the most widely used to overcome the limitations of human resources, but this has become a problem in its implementation. The negative impact of having a double position is the cost of labor salaries to be smaller because the employees employed are not too many [8].

The holders of hypertension prevention and control programs at the primary health care and the Sleman District Health Office also said that double occupation and high work intensity had an impact on fatigue and reduced work effectiveness, so that it could affect the success of a program. The existence of multiple positions allows health workers to often experience tension in work situations such as time pressure when performing tasks in standard work processes. Multiple job pressures allow a sense of the burden of responsibility to structure their own work among already busy main jobs [9].

This slightly contradicts the results of previous studies which state that performance will remain effective despite multiple positions if the leadership and a good internal control system have been implemented by the company, in addition to the factor of not too much work intensity that must be completed also becomes the reason for high work effectiveness despite dual position. This shows that the concurrent position is not a major obstacle in the implementation of a program if the leadership and internal control systems are determined to be good, but vice versa [8].

Cadre formation is also often used to overcome the shortage of human resources when implementing programs in the field. Most primary health care in Sleman District have conducted training for health cadres in their working areas. In general, elderly cadres have a role, namely as implementers, managers, and users. Before the activity is carried out, health cadres are first given training on programs to be carried out so that they are more skilled in carrying out their duties [10]. Strengthening human resources through public health training is also supported by the centers of disease control (CDC) through the epidemic intelligence service program, a program with a good model for training as public health practitioners in applied epidemiology. This model acts as a training for infectious diseases, and even such a training program can improve the quality of health resources through the identification of best practices to promote the integration of public health modeling [11]. Early awareness and disease surveillance officers also need to attend training and on average disease surveillance officers have many roles to play, so that training can support the quality of health workers [12].

This is in line with the results of previous research which states that there are differences in cadre skills in the health field between before and after training [13]. Health workers need to be trained according to standard care guidelines and protocols to strengthen the improvement in screening, diagnosis and management of risk factors for cardiovascular disease control. In addition health workers also need to be trained in health counseling in supporting screening and follow-up activities for patients [14].

\subsubsection{Facilities and infrastructure}

Based on the results of research conducted at 25 primary health care in Sleman Regency, it can be seen that the majority (92\%) health centers in Sleman regency have hypertension manuals or technical guidelines. This is also supported by the results of qualitative research. The following interview excerpts:

"There are SOPs, there certainly are, there are also those in the bag. " (Informant A)

"For the manual there." (Informant $C$ )

"There are (handbooks)." (Informant D)

Based on the results of research conducted in 25 primary health care in Sleman Regency, the results obtained are that all health centers in Sleman Regency have hypertension counseling media. This is also supported by the results of qualitative research. The following is an excerpt from the interview:

"There (IEC media), we always make, there is hypertension, diabetes. Yes, it has been (used by the community) but sometimes people do not care, with themselves sometimes do not care. On average, if people suffer from hypertension, there are no complaints yet, they don't want to be controlled, but my friends and I have told them that their main friends should often socialize to the community." (Informant A)

"Still limited (information and education communication media). Communication has been used but because it is limited so not all." (Informant B)

"Yes there is, like a leaflet." (Informant $C$ )

"There are, some are utilized and some are still lacking, " (Informant D) 
Based on quantitative and qualitative findings, it can be seen that all primary health care already have communication, information, and education (IEC) media, but in practice they are still underutilized by the community due to lack of awareness from the community itself. Based on Table 1, it can be seen that all primary health care in Sleman Regency have hypertension examination equipment such as tensimeter, stethoscope, as well as weight and height measurements. This is also supported by the results of qualitative research. The following interview excerpts:

"For hypertension, maybe only the blood pressure, tension, stethoscope, Posbindu kit, because the Posbindu kit is already in." (Informant A)

"Posbindu kit already exists." (Informant C)

"It's complete. A tensimeter is there, a scale is there, then a laboratory check tool is there." (Informant D)

The availability of the equipment has been assessed as complete, but based on interviews conducted it has been found that the amount is still considered insufficient. The following interview excerpts:

"We have limited equipment, not yet for the screening, prevention and control of hypertension activities such as blood pressure, but due to limitations, the community itself has an awareness to be independent, Ms." (Informant A)

"Still not enough, for the people." (Informant B)

"As for the amount, it's lacking, I'm currently submitting." (Informant D)

Facilities and infrastructure is one aspect of input that can support the success of the program. The completeness of good facilities and infrastructure is very important in creating customer satisfaction [15]. Based on the results of the research that has been done, it is known that the facilities and infrastructure supporting the prevention and control of hypertension programs in all primary health care in Sleman Regency have been considered complete, but according to the results interviews with several informants stated that although complete, the numbers were still considered to be lacking. The availability of PTM communication, information and education (IEC) media has also been available in all primary health care in Sleman Regency, but based on interviews obtained from informants stated that IEC media such as leaflets, posters, videos, and others are still not fully utilized by the community and officers. This is in line with the results of previous studies which stated that health service infrastructure has a moderate effect on patient satisfaction because even though a health care institution has been equipped with adequate facilities and infrastructure, if it is not functioned as fully as possible to serve patients it will be less can provide satisfaction to patients [15].

Health care services depend on the quality of infrastructure to improve services to patients. The availability of adequate infrastructure can provide a positive view of the quality of health services in the community, so that there is a positive relationship between the quality of infrastructure and the quality of health services [16]. The availability of facilities and gaps in the management of cardiovascular disease greatly affects the management of care at the primary level, if this gap exists then a strong system of cardiovascular health care is needed at the primary level to increase interventions in the prevention and management of chronic diseases to reduce the burden of universal [17]. An inefficient performance management system and a poor work culture can significantly contribute to high errors in health services. Clinics or hospitals are considered not to be better at providing services without adequate management of facilities and infrastructure [18]. Therefore, all health services related to health service management including care must pay attention to the performance of the infrastructure [19].

\subsubsection{Funding}

Based on Table 1, it is known that as many as $23(92 \%)$ program managers at the primary health care stated that the available funds were sufficient. This is also supported by the results of qualitative research. The following is an excerpt from the interview:

"Yes, we are forced to be enough because it has been plotted. Non communicable disease from health operational assistance has already allocated 200 million less, but even then we have to be smart in thinking about managing the budget for activities from here, from the district." (Informant A).

"In my opinion, the funds are sufficient. It's just that the funds were not given directly as PTM money." (Informant C)

"We carry out activities in accordance with the funds provided, for example we propose for 60 people to eat and drink, we are invited to 60 yes. So that can be said to be enough." (Informant D) 
Based on the quantitative and qualitative results, it can be seen that the funds provided are sufficient because the person in a charge of the program carries out activities in accordance with the funds set by the government. Based on Table 1, it is known that $24(96 \%)$ program managers at the primary health care stated that the funds provided were timely. This is also supported by the results of qualitative research. The following interview excerpts:

"Yes, right, because there is a deadline for us." (Informant A)

"Right on time. There is, accordingly. On time." (Informant B)

"Yes, it's quite right." (Informant C)

"Exactly, it depends on us." (Informant D)

The availability of funds used for the prevention and control of hypertension in Sleman Regency has been considered sufficient; this is because the funds provided have been rationed, so that program holders only carry out activities in accordance with the budget funds provided by the government. The timeliness in providing funding for the hypertension prevention and control program in Sleman Regency has also been assessed on time, because the funds spent have been devised by the government. The availability of funds affects the quality of health services provided by a health service agency [20]. One factor that is thought to affect the work motivation of officers is the speed of funds disbursement. If funds are disbursed more quickly at the beginning of the year, health workers are more comfortable working and do not have to be in debt or use personal money to carry out activities [21]. A financing mechanism must be developed in India to support health infrastructure at the primary and secondary levels and the existence of a publicly funded health insurance policy in the prevention and control of cardiovascular disease, this is done as a policy implementation to reduce the burden of cardiovascular disease deaths by 25-30\% [22]. Multiple funding in health services is beneficial for increasing flexibility and overall adequacy of funds. If there are sufficient funds, it can have an impact on the provision of a wider range of health services. The number of services available will improve the quality and protection of public health [23].

\subsection{Process aspect}

Process aspects in this research include the planning, implementation and supervision of the Posbindu, Posyandu Elderly and Prolanis programs. The results from the process aspects are as follows:

\subsubsection{Posbindu}

Based on quantitative results, it is stated that the majority of primary health care in Sleman Regency have carried out the Posbindu program process well. This is indicated by the fact that they have carried out Posbindu activities at least once a month in accordance with the standards. This is supported by the statement of the informant. The following is an excerpt from the interview:

“Posbindu every month, every 23rd but sometimes adjust.” (Informant E)

In addition to the implementation they have also carried out planning. This has also been supported by the statement of the informant. The following is an excerpt from the interview:

"In the beginning to stand up, there were only a few. Then we were offered Posbindu, then I had to coordinate first with regional stakeholders, then later I would socialize the cadres first, later if I did not socialize, the cadres would not want to, I would later be bothered, then all at will, finally I would accept and eventually join the technical guidance for 5 days." (Informant E)

In addition to implementation and planning, most primary health care have also conducted monitoring. This is also supported by statements from informants. The following is an excerpt from the interview:

"For example, in this village there is Posbindu, the biggest problem is where we evaluate it with participants. "(Informant C)

Based on the results obtained, it can be seen that the majority of primary health care in Sleman Regency have run the Posbindu process well, but even so there is still the process of implementing Posbindu that has not been carried out in accordance with the specified standards. Posbindu PTM runs routinely but is not in accordance with the technical guidelines Posbindu PTM, where the understanding of the implementers of the activities is not in accordance with the concepts contained in the technical guidelines [24]. The role of 
cadres is not optimal, the lack of cadres, the lack of funding sources, the lack of coordination of the results of activities with stakeholders and cadres become influential factors in the implementation of Posbindu activities [25].

\subsubsection{Elderly posyandu}

Based on quantitative results, it is known that the majority of primary health care in Sleman Regency have carried out the Posyandu program for the elderly well. This is indicated by the fact that they have conducted Posbindu activities at least once a month in accordance with the standards and have conducted 5 table activities in accordance with the guidelines of the implementation of the elderly Posyandu, but even so based on the results of interviews that have been carried out there are obstacles felt by one of the informants. The following interview excerpts:

\section{"The obstacle is if there are parents, we have to pick up and then deliver." (Informant F)}

The results of the interview show that the perceived obstacle is the lack of awareness from the community to independently come to the elderly Posyandu activities, so that in this case the role of cadres is needed to deliver the elderly Posyandu participants. The role of the cadre in the implementation of the Posyandu for the elderly or Posbindu has also been appreciated by the primary health care, namely rewards in the form of recreation. The following is an excerpt from the interview:

"Outbound, jambore Posbindu PTM. The reward is given to them because they have worked hard for helping us, the reward is outbound, the whole district. One primary health care is 4 thousand people, every year there is, this will also be there later." (Informant A)

"We might give more cadres later, for example strips of sugar, if later maybe when there is a meeting we will direct it more to outbound." (Informant C)

"Then, later as there is a term, Posbindu who is the most diligent, then will continue to be rewarded during meetings.” (Informant E)

Based on the research results obtained, it can be seen that the majority of primary health care in Sleman Regency have carried out the elderly Posyandu process well. The obstacle experienced is the lack of awareness of the community to independently come to the elderly Posyandu activities, so that the role of cadres is needed to deliver the elderly Posyandu participants. The role of cadres has also been appreciated by the primary health care, namely by giving rewards in the form of recreation. This is in line with the results of previous studies which state that in order to retain cadres, the primary health care provide rewards in the form of recreation or participation in socialization organized by the health office [26]. Programs carried out by the community responsible for reducing the risk of cardiovascular disease and community change carried out in the state of Maine can reduce poverty levels for more than 40 years when compared to other states [27]. One of the efforts to increase the coverage of elderly visits (elderly) to the elderly Posyandu is to equip cadres' skills through training. If cadres have sufficient knowledge and skills, it is hoped that cadres will have good abilities in conducting health counseling for the elderly and are able to make good decisions. After the training for elderly Posbindu cadres, it shows an increase in the score of knowledge and an increase in the skills of cadres in carrying out physical examinations and simple laboratory examinations [28].

\subsubsection{Prolanis}

Based on quantitative results it can be seen that the majority of primary health care in Sleman Regency have carried out the Prolanis program process well. This is indicated by the fact that they have carried out Prolanis activities in accordance with the provisions of the Prolanis manual. The following interview excerpts:

"Prolanists are a way, all are required to do Prolanis. Every family doctor, primary health care, clinical, Prolanis for diabetes and hypertension." (Informant A)

But in its implementation, there is one health center in Sleman Regency which only conducts diabetes mellitus Prolanis program and does not carry out hypertension Prolanis program, according to the health center program holder, this is due to limited human resources. Based on the results of the research that has been done, it can be seen that most primary health care have carried out the entire process from planning, implementation, and supervision well, but it is known that there is one primary health care that only conducts diabetes mellitus Prolanis but does not do hypertension Prolanis. After confirmation, the researchers found that this was due to the lack of human resources available at the primary health care so that hypertension 
Prolanis could not be implemented. Sufficient quantity of HR was needed to maximize existing health services [7]. Human resources that have not yet been trained as Prolanis implementers can influence the implementation of Prolanis activities that are running well or not [29]. The need to provide training to improve staff skills, update knowledge and cooperation between program managers at the primary health care [30].

\subsection{Output aspect}

The following is a description of the achievement of coverage of hypertension services according to 2018 standards primary health care in Sleman Regency can be described in Figure 1.

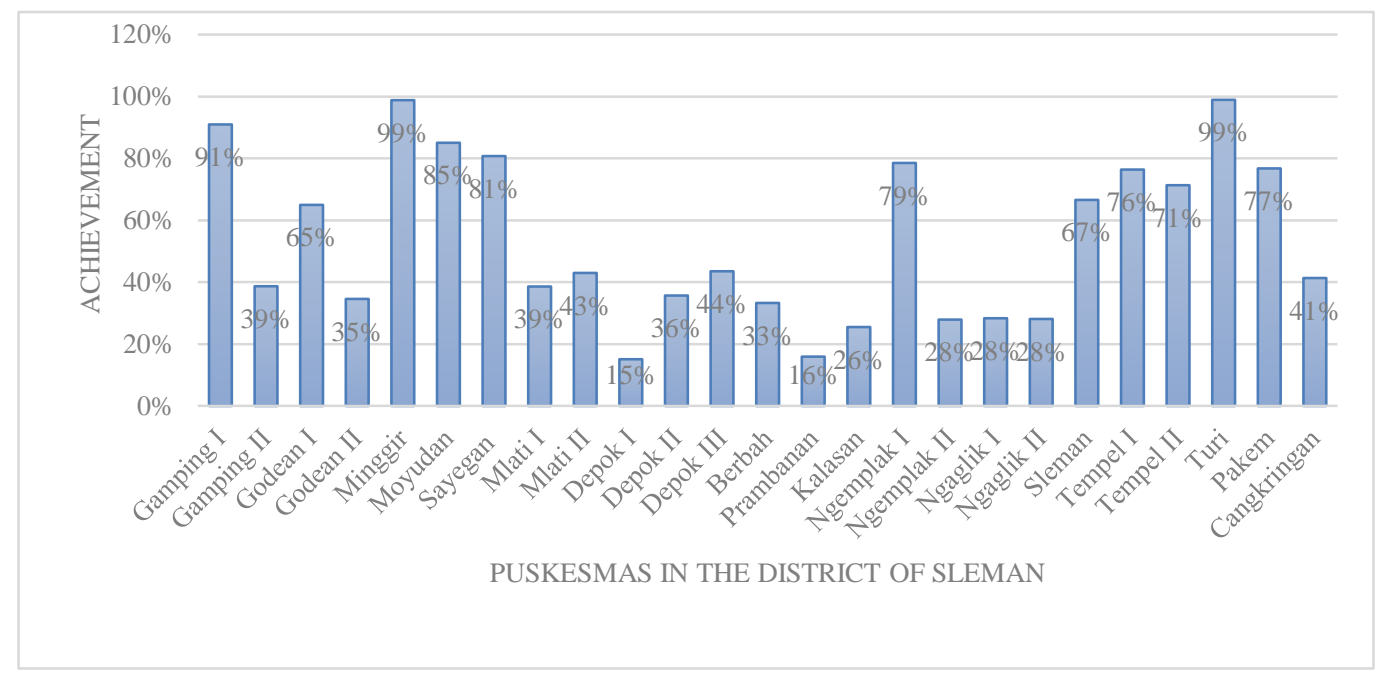

Figure 1. Achieving the coverage of hypertension services in accordance with 2018 standards per primary health care in Sleman Regency

Based on Figure 1, it can be seen that Turi Health Center is a health center that has the highest coverage of hypertension services at $99 \%$ of the $100 \%$ target, while Depok 1 Health Center is the health center that has the lowest hypertension service coverage at $15 \%$ of the $100 \%$ target. The coverage of hypertension services in Sleman Regency which has not yet reached the target is caused by several things. Qualitative results indicate that there are several obstacles that have caused the achievement of targets for coverage of hypertension services according to standards. The following is an excerpt from the interview:

"The obstacles are the limitations of HR." (Informant A)

"What is clear is that the first one was hindered because of limited manpower, right? The budget can be adjusted. Obviously there is a special officer there, because there are too many programs from the health ccenter, everyone has to hold some, that's the problem. Even though the workforce is also limited. You also calculate effectiveness, so between the top and the bottom is not synchronous for energy." (Informant B)

"HR, that's all. The fix is that the programmer has to be able to all, must give everything." (Informant $C$ )

"That clearly lacks energy, it's the holders who do the screening only. The solution is to form a team." (Informant D)

Based on the qualitative results, it can be seen that all informants make limited human resources as an obstacle in the implementation of the PJPD (hypertension) program in Sleman Regency. The output aspect can be seen from the hypertension service coverage data according to the standards obtained from the Sleman District Health Office in 2018. Based on the Republic of Indonesia Ministerial Regulation No. 43 of 2016 Concerning Minimum Service Standards in the Health Sector states that the performance achievements of District/City Governments in providing health services according to standards for hypertension sufferers, assessed from the percentage of the number of hypertensive patients who get health services according to the standards in their working area within one year. The target achievement of the performance of the 
Regency/City Government in providing health services to patients with hypertension or people with hypertension complaints according to the standard is $100 \%$. Based on the results obtained, it can be seen that Sleman Regency still does not meet the specified SPM target of 100\%. This means that there are still obstacles that affect the output results [31].

Based on the results of interviews with several informants, they stated that the main obstacles in the implementation of hypertension prevention and control programs were the lack of availability of human resources and lack of public awareness to make efforts to prevent hypertension. The quantity of HR influences the performance of existing health services [7]. The implementation of the program process will affect the output, if the process is not appropriate then the resulting output will also be inappropriate [32]

\section{CONCLUSION}

The prevention and control program of heart disease and internal medicine in Sleman Regency from the aspect of input for the funds is already good because it is in accordance with existing standards, while for human resources and infrastructure even though it is available, but the amount is still considered insufficient. Aspects of the process which includes planning, implementing, and monitoring the prevention and control of heart disease and internal medicine programs in Sleman Regency are already good because they are in accordance with the existing standards. Output aspects in prevention and control of heart disease and internal medicine in Sleman Regency are still not good because the results of the achievement of hypertension service coverage according to minimum service standards have not reached the target.

\section{ACKNOWLEDGEMENTS}

Authors express gratitude to Universitas Ahmad Dahlan for providing support in research funding. Authors also thank to primary health care and the Sleman District Health Office for providing data in this study.

\section{REFERENCES}

[1] S. S. Virani et al., "Heart disease and stroke statistics-2020 update: A report from the American Heart Association," Circulation, vol. 141, pp. E139-E596, 2020.

[2] R. Suhadi, H. Phebe, W. Yosef, et al., "The Ins and Outs of Hypertension: Increasing Clinical Competence for Pharmaceutical Services," Berkala Ilmiah Kedokteran Duta Wacana Sanata Dharma University Press, Yogyakarta, vol. 2, no. 3, 2016.

[3] Ministry of Health of the Republic of Indonesia, "Basic Health Research 2018," Ministry of Health of the Republic of Indonesia, Jakarta, 2017.

[4] Ministry of Health of the Republic of Indonesia, "Basic Health Research 2013" Health Research and Development Agency. Ministry of Health of the Republic of Indonesia, Jakarta, pp. 1-268, 2013.

[5] Public Health Office of DIY, "Profile of Yogyakarta Special Region Health 2017," Yogyakarta: Public Health Office of DIY, 2017.

[6] Arifudin, Sudirman, and M. Andri, "Evaluation of Human Resource Management System on Work Placement of Officers at UPT Puskesmas Lembasada," Promotion Journal Kesehatan Masyarakat, vol. 7, no. 1, pp. 1-14, 2017.

[7] H. A. Khariza, "National Health Insurance Program: A Descriptive Study of Factors That Can Affect the Success of Implementing the National Health Insurance Program at Menur Mental Hospital, Surabaya," Kebijakan dan Manajemen Publik, vol. 3, no. 1, pp. 1-7, 2015.

[8] B. A. Prasista, G. A. Yuniarta, and M. A. Wahyuni, "Analysis of the Effectiveness and Impact of Multiple Positions in Improving Organizational Performance At Pt. Treasure Ajeg Lestari, In Banyuning Village, Buleleng District," e-Journal S1 Ak Univiversitas Pendidikan Ganesha Jurusan Akuntansi Program S1, vol. 8, no. 2, pp, 1-10, 2017.

[9] G. Jutengren, E. Jaldestad, L. Dellve, and A. Eriksson, "The Potential Importance of Social Capital and Job Crafting for Work Engagement and Job Satisfaction among Health-Care Employees," International Journal Environmental Research Public Health, vol. 17, no. 12, pp. 4272, 2020.

[10] R. O. Handayani, A. Suryoputro, and A. Sriatmi, "Factors Related to Cadre Practices in Implementing Elderly Posyandu in Sendangmulyo Village, Tembalang District, Semarang City," Journal Kesehatan Masyarakat, vol. 6, no. 1, pp. 81-93, 2018.

[11] C. Rivers et al., "Using 'Outbreak Science' to Strengthen the Use of Models During Epidemics," Nature Communications, vol. 10, no. 3102, pp. 1-3, 2019.

[12] M. K. Manurung, S. E. Reo, J. F. Pardosi, and D. J. Muscatello, "Evaluation of the Indonesian Early Warning Alert and Response System (EWARS) in West Papua, Indonesia," WHO South-East Asia Journal Public Health, vol. 9, no. 2, pp. 111-117, 2020.

[13] N. Ulfah, B. Aji, and S. Harwanti, "Evaluation of the Ability of Health Cadres in Conducting Outreach Activities," Journal Kesmas Indonesia, vol. 9, no. 1, pp. 34-45, 2017.

[14] G. Musinguzi et al., "An implementation science study to enhance cardiovascular disease prevention in Mukono and Buikwe districts in Uganda: A stepped-wedge design," BMC Health Services Research, vol. 19, no. 253, pp. 1$10,2019$. 
[15] I. Y. Ristiani, "The Influence of Infrastructure and Service Quality on Patient Satisfaction (Study on Outpatient Patients at the IPDN Jatinegoro Polyclinic Unit)," Coopetition, vol. 7, no. 2, pp. 155-166, 2017.

[16] A. Jameel et al., "Improving Patient behavioral Consent through Different Service Quality Dimensions: Assessing the Mediating Role of Patient Satisfaction," International Journal Environmental Research Public Health, vol. 16, no. 23, p. 4736, 2019.

[17] A. Pakhare, S. Kumar, S. Goyal, and R. Joshi, "Assessment of primary care facilities for cardiovascular disease preparedness in Madhya Pradesh, India,” BMC Health Services Research, vol. 15, no. 408, pp. 1-8, 2015.

[18] N. S. Hamdan et al., "Investigating Factors of Service Quality Influencing Patient Satisfaction towards Patient Loyalty," International Journal Advanced Science Technology, vol. 28, no. 16, pp. 452-459, 2019.

[19] S. Swain and N. C. Kar, "Hospital service quality as antecedent of patient satisfaction - a conceptual framework," International Journal of Pharmaceutical and Healthcare Marketing, vol. 12, no. 2, pp. 251-269, 2018.

[20] F. Novanty and D. N. A. Ningrum, "Evaluation of Surveillance System Inputs for the Discovery of Tuberculosis (TB) Suspects in the Public Health Center in the Working Area of the Magelang District Health Office," Unnes Journal Public Health, vol. 5, no. 2, pp. 120-129, 2016.

[21] H. Mulyawan, L. Trisnantoro, and S. N. Zaenab, "Evaluation of the Implementation of Health Operational Assistance Policies at the Health Office (Case Study at the Bantul District Health Office and the Lebong District Health Office 2011)," Journal Kebijakan Kesehatan Indonesia, vol. 1, no. 3, pp. 144-153, 2012.

[22] R. Gupta, S. Guptha, R. Joshi, and D. Xavier, "Translating evidence into policy for cardiovascular disease control in India," Health Research Policy System, vol. 9, no. 8, pp. 1-12, 2011.

[23] M. E. Otim et al., "Characteristics and Effects of Multiple and Mixed Funding Flows to Public Healthcare Facilities on Financing Outcomes: A Case Study From Nigeria," Frontiers in Public Health, vol. 1, p. 403, 2020.

[24] G. Sicilia, F. S. T. Dewi, and R. S. Padmawati, "Qualitative Evaluation of Non-Communicable Diseases Program Based on Posbindu in the Work Area of Muara Bungo I Health Center," Journal Kebijakan Kesehatan Indonesia JKKI, vol. 7, no. 2, pp. 88-92, 2018.

[25] R. Eka Putri, "Evaluation Of Ptm Posbindu Implementation Process In The Working Area Of Puskesmas Simpang Duren River, Jambi District, Outside City, Muaro Jambi District Year 2017,” Journal Kesmas Jambi, vol. 2, no. 1, pp. 12-27, 2018.

[26] A. Kurniasari, A. Suryoputro, S. P. Arso, and A. Sriatmi, "Analysis of the Implementation of the Elderly Posyandu at the Bandarharjo and Krobokan Puskesmas Semarang City," Journal Kesehatan Masyarakat, vol. 6, no. 5, pp. 1-12, 2018.

[27] Record N.B, Onion D.K, Prior R.E et al., "Community-Wide Cardiovascular Disease Prevention Programs and Health Outcomes in a Rural County, 1970-2010," JAMA, vol. 313, no. 2, pp. 147-155, 2015, doi: 10.1001/jama.2014.16969.

[28] S. Indarjo, S. Indarjo, B. Hermawati, and E. Nugraha, "Non-Communicable Diseases Training Post (Posbindu PTM) Efforts at Posyandu Cadres in Kalikayen Village, Kec. East Ungaran, Kab. Semarang," Journal Abdimas, vol. 23, no. 2, pp. 134-138, 2019.

[29] Rosdiana et al., "59/5000 Implementation of the Chronic Disease Management Program (Prolanis)," Higeia Journal of Public Health Research and Development, vol. 1, no. 3, pp. 40-150, 2017.

[30] A. Meiriana, L. Trisnanto, and R. S. Padmawati, "Implementation of the Chronic Disease Management Program (Prolanis) in Hypertension at the Jetis Health Center, Yogyakarta City," Journal Kebijakan Kesehatan Indonesia JKKI, vol. 8, no. 2, pp. 51-58, 2018.

[31] Puskesmas Nglipar II, "Profile Report of UPT Puskesmas Nglipar II 2017," Center for Data and Information of the Ministry of Health of the Republic of Indonesia, Jakarta, pp. 1-10, 2017.

[32] D. F. Radina and N. A. Damayanti, "95/5000 Evaluation of the Implementation of Minimum Service Standards in the Infant Pneumonia Patient Discovery Program," Journal Administrasi Kesehatan Indonesia, vol. 1, no. 4, pp. 301-308, 2013. 